
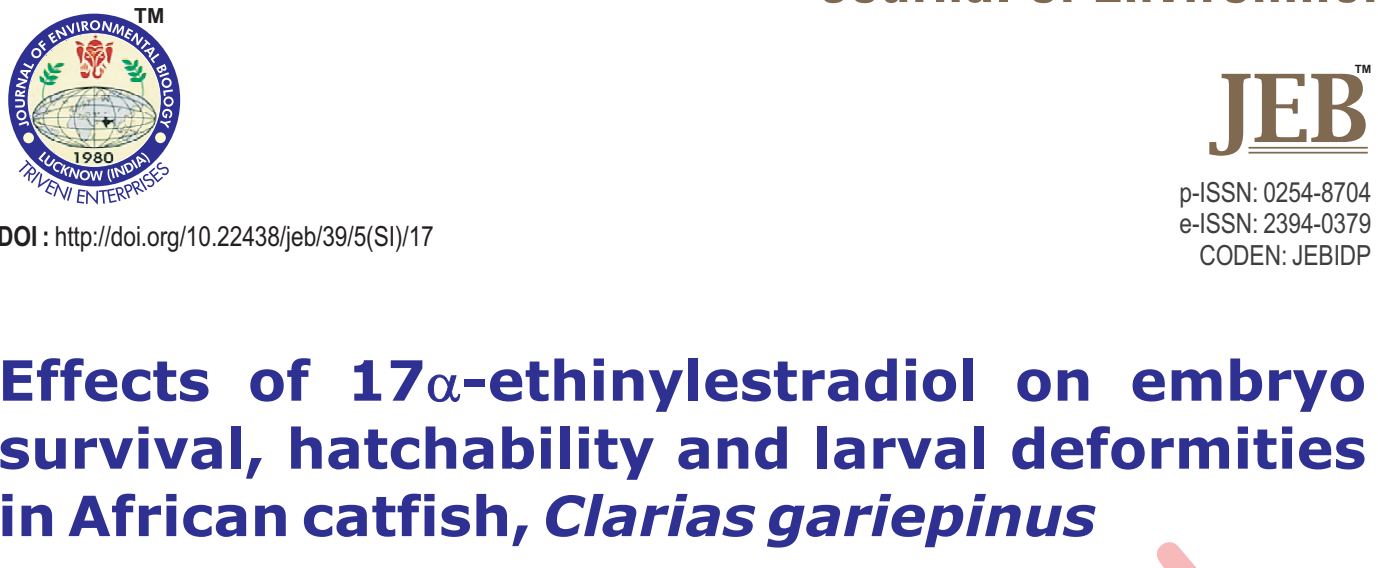

\title{
Effects of $17 \alpha$-ethinylestradiol on embryo survival, hatchability and larval deformities in African catfish, Clarias gariepinus
}

Authors Info

M. Nadirah ${ }^{1,2 *}$, M. A. B. Tajuddin', M. Najiah ${ }^{1,2}$, M. Abd Ghaffar ${ }^{1,2,3}$ and K.L. Lee ${ }^{1}$

${ }^{1}$ School of Fisheries and Aquaculture Sciences, Universiti Malaysia Terengganu, 21030, Terengganu, Malaysia

${ }^{2}$ Institute of Tropical Aquaculture, Universiti Malaysia Terengganu, 21030, Terengganu, Malaysia

${ }^{3}$ Marine Ecosystem Research Center, Faculty of Science and Technology, Universiti Kebangsaan Malaysia, 43600 Bangi, Selangor, Malaysia

${ }^{*}$ Corresponding Author Email : nadirah@umt.edu.my

Key words

17a-Ethinylestradiol

Clarias gariepinus

Embryonic development

Hatchability

Larval deformities

Publication Info

Paper received : 16.05.2016

Revised received : 20.06.2016

Re-revised received : 12.01.2017

Accepted : 28.12.2017

\section{Abstract}

Aim : Synthetic estrogens, such as $17 a$-ethinylestradiol $\left(E_{2}\right)$, are common in contraceptive pills, and $\mathrm{EE}_{2}$ levels may be present in various waterways. As such qualitative and quantitative assessment on the impact of $\mathrm{EE}_{2}$ on aquatic organisms are needed. The main objective of the study was to determine the effect of $E_{2}$ at the environmentally relevant concentrations on embryonic survival, hatchability and larval deformities in African catfish (Clarias gariepinus) cultured under laboratory conditions.

Methodology : Two healthy sexually mature males and two gravid female fish weighing 0.8 to $1.0 \mathrm{~kg}$ were selected based on the external morphological features. They were then subjected to induced breeding with ovaprim, given at 0.25 b.wt. and $0.5 \mathrm{ml} \mathrm{kg}^{-1}$ b.wt. for males and females, respectively. Eight hundred fertilized eggs (embryos) were randomly distributed into four groups with 100 eggs per group in duplicate in respective concentrations of $\mathrm{EE}_{2}$ : control $\left(0 \mathrm{ngl}^{-1}\right), 25 \mathrm{ngl}^{-1}, 50 \mathrm{ngl}^{-1}$ and $100 \mathrm{ng} \mathrm{l}^{-1}$, each in $1000 \mathrm{ml}$ glass beakers. Percentage of normal embryonic survival and abnormalities were recorded prior to hatching at $30^{\text {th }}$ hour post fertilization (hpf), while 20 post-hatch larvae were sampled randomly from each group to determine the number of larvae displaying morphological deformities.

Results : At $30^{\text {th }} \mathrm{hpf}$, only $62 \%$ of the eggs survived when incubated with $100 \mathrm{ngl}^{-1}$ of $\mathrm{EE}_{2}$, while the highest survival was observed in the control group (92\%). The lowest hatching success rate of $55 \%$ was seen in the $100 \mathrm{ng} \mathrm{l}^{-1}$ group, which was significantly lower from the embryos exposed to 0 or $25 \mathrm{ng} \mathrm{l}^{-1}$.

Interpretation : The results suggest that $\mathrm{EE}_{2}$ at $100 \mathrm{ng} \mathrm{l}^{-1}$ affected the early life stages of $C$. gariepinus, thus, a closer monitoring on $\mathrm{EE}_{2}$ discharge into the aquatic environments is essential.

Two pairs of sexually matured broodstock of Clarias gariepinus

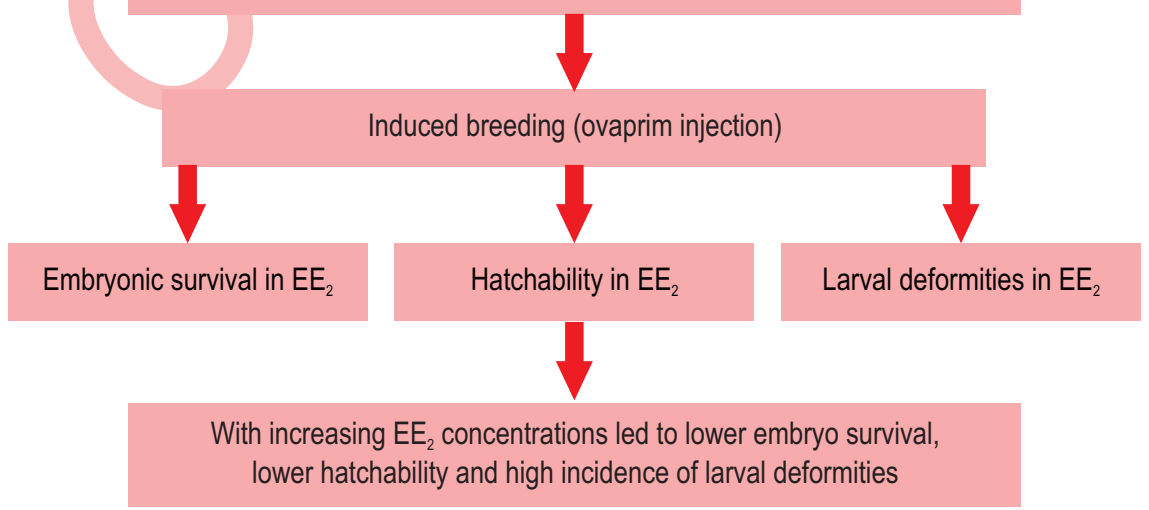




\section{Introduction}

Bioassay techniques are keystones for toxicity testing, which helps detect potential threats of either naturally occurring or man-made chemical compounds. In non-mammalian vertebrates, aquatic bioassay provides an excellent tool for this purpose, however, the effect may vary with species and life stages. Compared with the adult stage, early stages of organisms are considered to be the most sensitive to environmental stress (Buikema, 1982; Rasowo, 2007). This is due, in part, to fish embryos and larvae lacking functionally developed gills and kidneys, thus there is increased passive absorption of chemicals from the aquatic environment. Various groups of chemicals are released in to the aquatic ecosystems and, among these, synthetic estrogens such as 17 a-ethinylestradiol $\left(E_{2}\right)$, in surface waters have been reported to be less than $5 \mathrm{ng} \mathrm{l}^{-1}$ (UK Environment Agency, 2002) but higher levels of $17.2 \mathrm{ng} \mathrm{l}^{-1}$ (Beck et al., 2005), $42 \mathrm{ngl}^{-1}$ (Ternes et al., 1999) and $831 \mathrm{ngl}^{-1}$ (Kolpin et al., 2002) have also been reported. $\mathrm{EE}_{2}$ is mostly found in oral contraceptive pills, prescribed at an average daily dose of 30-35 $\mu \mathrm{g}$ per pill (Wise et al., 2010), as well as being used in hormone replacement therapies (Desbrow et al., 1998; Gutendorf and Westendorf, 2001).

$\mathrm{EE}_{2}$ is known as a potent synthetic estrogen that also acts as an endocrine disruptor in fish (Kime, 1998). It has strong affinity for the estrogen receptor (Dietrich and Krieger, 2009; Hogan et al., 2010) with the ability to concentrate in fish tissue (Thorpe et al., 2003; Soares et al., 2009). Endocrine disruption has been suggested as the possible cause of reproductive abnormalities for many animal species in the wild. These abnormalities are evident at the early stages of development because some permanent effects may appear, such as various body malformations. Estrogens play an essential role equally in reproduction and somatic cell function, sexual differentiation, ovulation, regulation of mating and breeding, as well as other biological processes such as maintaining mineral and water homeostasis (Fairbrother, 2000).

In the laboratory, at environmentally relevant concentrations, $\mathrm{EE}_{2}$ causes alterations in the reproductive function of many animals (Jobling et al., 1995; Giesy et al., 2000; Fenske et al., 2005). For instance, intibition of spawning in medaka fish, Oryzia melastigma exposed to $50-100 \mathrm{ng} \mathrm{l}^{-1} \mathrm{EE}_{2}$ for 14 days (Lee et al., 2014). Chronic exposure of zebrafish Danio rerio to $5 \mathrm{ng} \mathrm{l}^{-1} \mathrm{EE}_{2}$ caused a $56 \%$ reduction in fecundity with no reported fertilization success (Nash et al., 2004). Microarray analyses of gonads in adult zebrafish exposed to $5 \mathrm{ng} \mathrm{l}^{-1} \mathrm{EE}_{2}$ significantly changed the expression of genes located in the ovaries and testes (Santos et al., 2007). Most studies on $\mathrm{EE}_{2}$ have been focusing on sexually mature adult fish (Van den Belt et al., 2003; Xu et al., 2008). To date, little information is available on the effect of $E_{2}$ on early life stages of fish with most studies focusing on small experimental fish models such as zebrafish (Soares et al., 2009). This study was undertaken to determine the dosedependent effect of 17a-ethinylestradiol on the early life stages of African catfish Clarias gariepinus, one of the most commonly consumed commercial freshwater aquaculture species in South EastAsia.

\section{Materials and Methods}

Broodstock : Two healthy sexually mature males and two gravid female fish weighing 0.8 to $1.0 \mathrm{~kg}$ were selected, based on the external morphological features described by Ayinla et al. (1994). Mature male fish was identified by a slightly pointed genital papilla, whereas the females were identified by a swollen abdomen and a reddish swollen vent. The fish were kept in individual tanks and fed ad libitum with fish feed (35\% crude protein) twice daily ( 7 am and $5 \mathrm{pm}$ ) to satiation based on $5 \%$ of the total fish biomass. The broodstock were acclimated in their new environment for at least 3 days at $28 \pm 2^{\circ} \mathrm{C}$ under normal 12 hrs light: $12 \mathrm{hrs}$ dark photoperiodic regime, with water $\mathrm{pH}$ ranging from 6.1 to 6.8 and dissolved oxygen 6.8 to $7.5 \mathrm{mgl}^{-1}$.

The females were administered with ovaprim at $0.50 \mathrm{ml}$ $\mathrm{kg}^{-1} \mathrm{~b}$.wt. whereas the males were administered with $0.25 \mathrm{ml} \mathrm{kg}^{-1}$ b.wt. All ovaprim-induced breeding was administered at 22:00 hrs. Briefly, the fish was covered with wet towel, and Ovaprim was injected intramuscularly above the lateral line towards the dorsal section and pointed towards the ventral side. After withdrawing the needle, the fish was finger-rubbed to avoid the backflow of the injected fluid. The injected fish was returned to their respective tanks. Approximately, $10 \mathrm{hrs}$ after the administration of ovaprim, the pre-weighed females were examined for their ovulatory response. The release of eggs through the genital pore following gentle pressure on the abdomen was considered as a commencement of ovulation and the eggs were stripped into fertilization trays. Testes were then removed from the males, and sperm was squeezed into a clean petri dish and mixed with the eggs.

Embryonic development and hatchability : The stripped eggs were pooled and fertilized with the pooled sperm suspension diluted with saline solution. After 2 min of gentle stirring, the fertilized eggs were washed several times with fresh water to remove any excess milt. The eggs were spread into a single layer on suspended nylon mesh for incubation. One hour post fertilization, the unfertilized eggs were removed carefully from the incubation tank. A sample of 800 fertilized eggs (embryos) were randomly distributed into four groups with 100 eggs per group in duplicate: control $\left(0 \mathrm{ngl}^{-1}\right), 25 \mathrm{ng} \mathrm{l}^{-1}, 50 \mathrm{ng} \mathrm{l}^{-1}$ and $100 \mathrm{ng} \mathrm{l}^{-1}$, each in $1,000 \mathrm{ml}$ glass beakers. Aeration was provided at a rate of 30 fine bubbles per minute. A stock solution of $\mathrm{EE}_{2}(>98 \%$ purity, SigmaAldrich, USA) was freshly prepared by dissolving the reagent in ethanol. The stock solution was diluted to their respective concentrations with dechlorinated tap water containing $0.01 \%$ ethanol for the control and treatment groups (Lee et al., 2014). 

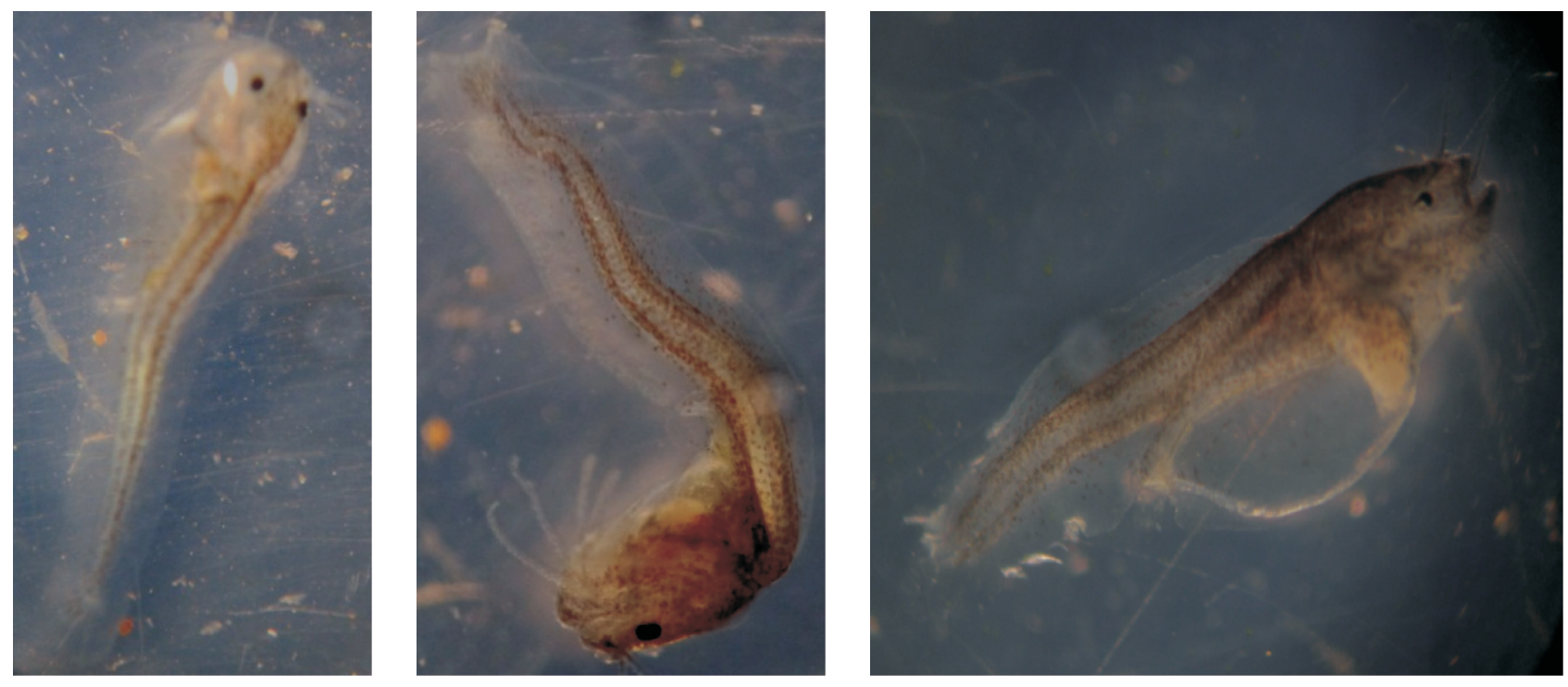

Fig. 1 : Normally developed type of deformities in larvae of Clarias gariepinus (far left), larvae with scoliosis (middle) and with yolk sac edema and gaped jaw (far right)

Water temperature, $\mathrm{pH}$ and dissolved oxygen levels were measured every 8 hrs during the experimental period. The percentage of embryo survival and abnormalities were recorded prior to hatching at $30^{\text {th }}$ hour post fertilization (hpf). In addition, the hatching rate was also recorded and expressed as follows:

\section{No. of eggs incubated - No. of unhatched eggs $\times 100$ No. of eggs incubated}

Larval deformities : Following hatching, 20 post-hatch larvae were sampled randomly from each group, and the number of larvae displaying morphological deformities were recorded and photographed.

Statistical analyses : Statistical analyses were performed with SPSS version 20. Shapiro-Wilk's test was used to check the assumption of normality, and Levene's test was used to check the assumption of homogeneity of variance. The influence of $\mathrm{EE}_{2}$ on survival rate, hatching rate and percentage of post-hatch larvae abnormalities among the groups were analyzed by one way. Percentage data was ANOVA transformed prior to analyses. The data was presented as mean $\pm S D$ and significance level was considered at $p<0.05$.

\section{Results and Discussion}

The perusal of data showed a dose-dependent relationship between the tested $\mathrm{EE}_{2}$ concentrations and the parameters measured. At $30^{\text {th }} \mathrm{hpf}$, only $62 \%$ of the eggs survived when incubated with $100 \mathrm{ng} \mathrm{I}^{-1}$ of $\mathrm{EE}_{2}$, which was significantly lower compared with the other groups (Table 1). The highest survival was observed in the control group at $92 \%$, as well as hatchability. Both hatchability and survival in the control group, were, not significantly different from 25 and $50 \mathrm{ng} \mathrm{l}^{-1}$ groups. The lowest hatching success rate of $55 \%$ was seen in the $100 \mathrm{ng} \mathrm{l}^{-1}$ group, which was significantly different from embryos exposed to 0 or $25 \mathrm{ngl}^{-1}$.

In addition, the number of newly hatched larvae with abnormalities increased with the increasing concentrations of $\mathrm{EE}_{2}$. The incidence of deformity was $5 \%$ at $100 \mathrm{ng} \mathrm{l}^{-1}$, and was significantly higher $(p<0.05)$ than the other groups (Table 2). Scoliosis, yolk sac edema and gaped jaws were among the deformities observed (Fig.1). The tested water quality parameters were similar among the treatments and were within the acceptable range for $C$. gariepinus eggs (Table 3 ), therefore, the cause for these findings was due to $\mathrm{EE}_{2}$ concentrations.

One of the key active compounds found in birth control pills is 17a-ethinylestradiol $\left(E_{2}\right)$, which is a synthetic estrogen and potent endocrine modulator (Desbrow et al., 1998; Langston et al., 2005). This has been shown to exert a range of estrogenic effects in fish at environmentally relevant concentrations (Purdom etal., 1994; Thorpe et al., 2003).

In this study, $100 \mathrm{ng} \mathrm{l}^{-1} \mathrm{EE}_{2}$ reduced the embryo survival, hatching success rate but increased the percentage of larval deformities, compared with 25 and $50 \mathrm{ng} \mathrm{l}^{-1}$. As such $100 \mathrm{ng} \mathrm{I}^{-1}$ may not be the teratogenic threshold for African catfish. However, the threshold could be more than $50 \mathrm{ng} \mathrm{l}^{-1}$ but less than $100 \mathrm{ng} \mathrm{l}^{-1}$, which were not covered in the present study. A similar observation was also reported by Versonnen and Janssen (2004), where zebrafish exposed to $100 \mathrm{ng} \mathrm{l}^{-1} \mathrm{EE}_{2}$ showed significant effects on the survival, hatching and growth. Previous studies have also revealed a significant concentration-dependence in hatching 
Table 1: Percentage of embryonic survival after 30 days and hatchability of Clarias gariepinus exposed to increasing concentrations of $\mathrm{EE}_{2}$

\begin{tabular}{lll}
\hline $\mathrm{EE}_{2}\left(\mathrm{ng} \mathrm{l}^{-1}\right)$ & Embryo survival & Hatchability \\
\hline 0 & $92.0 \pm 3.0^{\mathrm{a}}$ & $70.0 \pm 2.0^{\mathrm{a}}$ \\
25 & $89.0 \pm 4.0^{\mathrm{a}}$ & $65.0 \pm 2.0^{\mathrm{a}}$ \\
50 & $82.0 \pm 5.0^{\mathrm{a}}$ & $63.0 \pm 2.0^{\mathrm{ab}}$ \\
100 & $62.0 \pm 9.0^{\mathrm{b}}$ & $55.0 \pm 2.0^{\mathrm{b}}$ \\
\hline
\end{tabular}

*Different superscript letters indicate significant differences $(p<0.05)$; Values are mean \pm SD.

Table 2: Percentage of newly-hatched larvae with deformities in Clarias gariepinus exposed to increasing concentrations of $\mathrm{EE}_{2}$

\begin{tabular}{ll}
\hline $\mathrm{EE}_{2}\left(\mathrm{ng} \mathrm{l}^{-1}\right)$ & Larval deformities (\%) \\
\hline 0 & $1.0 \pm 0.0^{\mathrm{a}}$ \\
25 & $1.5 \pm 0.7^{\mathrm{a}}$ \\
50 & $2.5 \pm 0.7^{\mathrm{a}}$ \\
100 & $5.0 \pm 2.8^{\mathrm{b}}$ \\
\hline
\end{tabular}

${ }^{*}$ Different superscript letters indicate significant differences $(p<0.05)$; Values are mean \pm SD.

Table 3 : Minimum and maxium temperature $\left({ }^{\circ} \mathrm{C}\right), \mathrm{pH}$ and dissolved oxygen (DO in $\mathrm{mgl}^{-1}$ ) throughout the study

\begin{tabular}{lll}
\hline Parameters & Minimum & Maximum \\
\hline Temperature & 26.5 & 28.9 \\
pH & 6.3 & 6.9 \\
DO & 6.9 & 7.5 \\
\hline
\end{tabular}

success to sheepshead minnow (Zillioux et al., 2001) and mummichog (Peters et al., 2010) exposed to 200 and $100 \mathrm{ng} \mathrm{l}^{-1}$ $\mathrm{EE}_{2}$, respectively. In contrast, no differences were observed in survival, weight or length of hatched medaka exposed for 2 months to 1, 10 and $100 \mathrm{ng} \mathrm{l}^{-1} \mathrm{EE}_{2}$ (Scholz and Gutzeit, 2000). However, a later study showed the fertilization rate and hatchability in Japanese medaka decreased at $500 \mathrm{ng} \mathrm{r}^{-1} \mathrm{EE}_{2}$ (Tilton et al., 2005). These findings may best be explained by interspecies differences. For instance, expression of estrogen receptors $E R a$ and $E R \beta$ in fish gonads and liver have been shown to differ between the species (Socorro et al., 2000; Tchoudakova et al., 1999). In addition, $\mathrm{EE}_{2}$ has been demonstrated to enhance the expression of the CYP19A2 gene in zebrafish (Kazeto et al., 2004) and medaka (Scholz and Gutzeit, 2000), which codes for an aromatase enzyme that mediates the conversion of androgen to estrogen. CYP19A2 has been detected in the brain of developing embryo of killifish, Fundulus heteroclitus (Dong and Willet, 2008).

In the present study, as the $\mathrm{EE}_{2}$ concentration increased, the number of larval abnormalities increased, and was significantly higher at the highest concentrations used $\left(100 \mathrm{ng} \mathrm{l}^{-1}\right)$. Several types of deformities were observed in this study i.e., fused vertebrae, scoliosis, gaped jaw and yolk sac edema. According to Onuoha and Nwadukwe (1990), spinal flexures of the larvae appeared to be a common response to various environmental stresses during ontogenic development. In this study, observation showed disturbances in the swimming behaviour of the larvae with deformities in addition to appearing less energetic.

The results of the present study, revealed that a relatively short exposure of C. gariepinus embryos and larvae to $100 \mathrm{ng} \mathrm{l}^{-1}$ $\mathrm{EE}_{2}$ adversely affected their embryonic development, hence reduced survival and hatchability rates, as well as larval deformities. Similar to the results of a study previously conducted on roach, Rutilus rutilus, by the UK Environment Agency (2008), the results of this study suggested that $\mathrm{EE}_{2}$ at $100 \mathrm{ng} \mathrm{l}^{-1}$ affected the early life stages of $C$. gariepinus, thus, warrants closer monitoring on $\mathrm{EE}_{2}$ discharge into the aquatic environments.

It is concluded that $\mathrm{EE}_{2}$ at $100 \mathrm{ng} \mathrm{I}^{-1}$ poses a potential teratogenic risk to the early life stages of $C$. gariepinus. Further investigations on the mechanisms of $E_{2}$ on early life stages of $C$. gariepinus are required, particularly at the molecular level which can be integrated to be informative from an ecological point of view.

\section{Acknowledgment}

The authors would like to thank the School of Fisheries and Aquaculture Sciences, Universiti Malaysia Terengganu for providing the research facilities.

\section{References}

Ayinla, O. A., O. Kayode, T.I.E. Idoniboye-Obu, A. Oresegun and V.E. Adidu: Use of tadpole meal as substitute for fish meal in the diet of H. bidorsalis (Geoffrey St. Hillarie 1809). J. Aqua. Trop., 9, 25-33 (1994).

Beck, I. C., R. Bruhn, J. Gandrass and W. Ruck: Liquid chromatographytandem mass spectrometry analysis of estrogenic compounds in coastal surface water of the Baltic Sea. J. Chrom. A., 1090, 98-106 (2005).

Buikema, A.L (Jr)., B.R. Neiderlehner and J(Jr). Cairns: Biological Monitoring: Part IV-Toxicity testing. Water Res., 16, 239-262 (1982).

Desbrow, C., E.J. Routledge, G.C. Brighty, J.P. Sumpter and M. Waldock: Identification of estrogenic chemicals in STW effluent. Chemical fractionation and in vitro biological screening. Environ. Sci. Technol., 32, 1549-1558 (1998).

Dietrich, D.R. and H.O. Krieger: Histological analysis of endocrine disruptive effects in small laboratory fish. John Wiley \& Sons Inc., 1, pp. 19-133 (2009).

Dong, W. and K.L. Willett: Local expression of CYP19A1 and CYP19A2 in developing and adult killifish (Fundulus heteroclitus). Gen. Comp. Endocrinol., 155, 307-317 (2008).

Fairbrother, A.: Comparative aspects of estrogen functions and measurements in oviparous and viviparous vertebrates. Hum. Ecol. RiskAssess., 6, 73- 102 (2000). 
Fenske, M., G. Maack, C. Schafers and H. Segner: An environmentally relevant concentration of estrogen induces arrest of male gonad development in zebrafish, Danio rerio. Environ. Toxicol. Chem., 24, 1088-1098(2005).

Giesy, J.P., S.L. Pierens, E.M. Snyder, S. Miles-Richardson, V.J. Kramer, S.A. Snyder, K.M. Nichols and D.A. Villeneuve: Effects of 4nonylphenol on fecundity and biomarkers of estrogenicity in fathead minnows (Pimephales promelas). Environ. Toxicol. Chem., 19, 1368-1377 (2000).

Gutendorf, B. and J. Westendorf: Comparison of an array of in vitro assays for the assessment of the estrogenic potential of natural and synthetic estrogens, phytoestrogens and xenoestrogens. Toxicol., 166, 79-89 (2001).

Hogan, N. S., S. Currie, S. LeBlanc, M.L. Hewitt and D.L. MacLatchy: Modulation of steroidogenesis and estrogen signalling in the estuarine killifish (Fundulus heteroclitus) exposed to ethinylestradiol. Aquat. Tox., 98, 148-156 (2010).

Jobling, S., T. Reynolds, R. White, M.G. Parker and J.P. Sumpter: A variety of environmentally persistent chemicals, including some phthalate plasticizers, are weakly estrogenic. Environ. Hith. Perspect., 103, 582-587 (1995).

Kazeto, Y., A.R. Place and J.M. Trant: Effects of endocrine disrupting chemicals on the expression of CYP19 genes in zebrafish (Danio rerio) juveniles. Aqua. Toxicol., 69, 25-34 (2004).

Kime, D.H.: Endocrine disruption in fish. Kluwer Academic Publishers, Norwell, MA(1998).

Kolpin, D.W., E.T. Furlong, M.T. Meyer, E.M. Thurman, S.D. Zaugg, L.B. Barber and H.T. Buxton: Response to comment on Pharmaceuticals, hormones, and other organic wastewater contaminants in US streams, 1999-2000: A national reconnaissance. Environ. Sci. Technol., 36, 4007-4008 (2002).

Langston, W.J., G.R. Burt, B.S. Chesman and C.H. Vane: Partitioning, bioavailability and effects of oestrogens and xeno-oestrogens in the aquatic environment. J. Mar. Biol. Assoc. UK, 85, 1-31 (2005).

Lee, P.Y., C.Y. Lin and T.H. Chen: Environmentally relevant exposure of 17a-ethinylestradiol impairs spawning and reproductive behaviour in the brackish medaka Oryzias melastigma. Mar. Poll. Bull., 85, 338-343 (2014).

Nash, J.P.: Long-term exposure to environmental concentrations of the pharmaceutical ethynylestradiol causes reproductive failure in fish. Environ. Hlth. Prospect., 112, 1725-1733 (2004).

Onuoha, G.C. and F.O. Nwadukwe: Influence of liquid petroleum refinery effluent on the hatching success of Clarias gariepinus (African mud fish) eggs. Environ. Ecol., 8, 1201-1206 (1990).

Peters, R.E.M., S.C. Courtenay, S. Cagampan, M.L. Hewitt and D.L. MacLatchy: Effects on reproductive potential and endocrine status in the mummichog (Fundulus heteroclitus) after exposure to 17aethynylestradiol in a short-term reproductive bioassay. Aquat. Toxicol., 85, 154-166 (2007).

Purdom, C.E., P.A. Hardiman, V.J. Bye, N.C. Eno, C.R. Tyler and J.P. Sumpter: Estrogenic effects of effluents from sewage treatment works. Chem. Ecol., 8, 275-85 (1994).

Rasowo, J., E.O. Oyoo and C.C. Ngugi: Effects of formaldehyde, sodium chloride, potassium permanganate and hydrogen peroxide on hatch rate of African cafish Clarias gariepinus eggs. Aquaculture, 269, 271-277 (2007).
Santos, E.M., G.C. Paull, K.J.W. Van-Look, V.L. Workman, W.V. Holt, V.R. Aerle, P. Kille and C.R. Tyler: Gonadol transcriptome responses and physiological consequences of exposure to oestrogen in breeding zebrafish (Danio rerio). Aquat. Tox., 83, 134142 (2007).

Scholz, S. and H.O. Gutzeit: 17a-ethinylestradiol affects reproduction, sexual differentiation and aromatase gene expression of the medaka (Oryzias latipes). Aquat. Tox., 50, 363-373 (2000).

Soares, J., A.M. Coimbra, M.A. Reis-Henriques, N.M. Monteiro, M.N. Vieira, J.M.A. Oliveira and P. Guedes-Dias: Disruption of zebrafish (Danio rerio) embryonic development after full life-cycle parental exposure to low levels of ethinylestradiol. Aquat. Tox., 95, 330-338 (2009).

Socorro, S., D.M. Power, P.E. Olsson and A.V.M. Canario: Two estrogen receptors expressed in the teleost fish, Sparus aurata: cDNA cloning, characterization and tissue distribution. J. Endocrinol., 166, 293-306 (2000).

Tilton, S.C., C.M. Foran and W.H. Benson: Relationship between ethinylestradiol-mediated changes in endocrine function and reproductive impairment in Japanese medaka (Oryzias latipes). Environ. Toxicol. Chem., 24, 352-359(2005).

Ternes, T.A., M. Stumpf, J. Mueller, K. Haberer, R.D. Wilken and M. Servos: Behavior and occurrence of estrogens in municipal sewage treatment plants - I. Investigations in Germany, Canada and Brazil. Sci. Total Environ., 225, 81-90 (1999).

Tchoudakova, A., S. Pathak and G.V. Callard: Molecular cloning of an estrogen receptor b subtype from the goldfish, Carassius auratus. Gen. Comp. Endocrinol., 113, 388-400 (1999).

Thorpe, K.L., R.I. Cummings, T.H. Hutchinson, M.S. Scholze, G. Brighty, J.P. Sumpter and C.R. Tyler: Relative potencies and combination effects of steroidal estrogens in fish. Environ. Sci. Technol., 37, 1142-1149 (2003).

UKEnvironmentAgency: Proposed Predicted-No-Effect-Concentrations (PNECs) for Natural and Synthetic Steroid Estrogens in Surface Waters; Bristol, UK (2002).

UK Environment Agency: Ontogeny of sexual development in the roach (Rutilus rutilus) and its interrelationships with growth and age; Bristol, UK (2008).

Van den Belt, K., R. Verheyen and H. Witters: Effects of 17aethinylestradiol in a partial life-cycle test with zebrafish (Danio rerio): Effects on growth, gonads and female reproductive success. Sci. Total Environ., 309, 127-137 (2003).

Versonnen, B.J. and C.R. Janssen: Xenoestrogenic effects of ethinylestradiol in zebrafish (Danio rerio). Environ. Toxicol., 19, 198-206 (2004).

Wise, A., K. O'Brien and T. Woodruff: Are oral contraceptives a significant contributor to the estrogenicity of drinking water? Environ. Sci. Technol., 45, 51-60 (2010).

Xu, H., J. Yang, Y. Wang, Q. Jiang, H. Chen and H. Son: Exposure to 17aethinylestradiol impairs reproductive functions of both male and female zebrafish (Danio rerio). Aquat. Toxicol., 88, 1-8 (2008).

Zillioux, E.J., I.C. Johnson, Y. Kiparissis, C.D. Metcalfe, J.V. Wheat, S.G. Ward and $\mathrm{H}$. Liu: The sheepshead minnow as an in vivo model for endocrine disruption in marine teleosts: A partial life-cycle test with 17a-ethynylestradiol. Environ. Toxicol. Chem., 20, 1968 -1978 (2001). 